\title{
FIRST RECORD OF THE COMMON GRACKLE FROM SONORA
}

\author{
DAVID VANDER PLUYM and LAUREN B. HARTER, 2841 McCulloch Blvd N. \#1, \\ Lake Havasu City, Arizona 86403; dvanpluym@gmail.com, lbharter@gmail.com
}

The Common Grackle (Quiscalus quiscula) is common in eastern North America, and since the 1970s has steadily spread west. It now breeds as far west as eastern British Columbia and central New Mexico, and records of vagrants elsewhere in the West have increased (Peer and Bollinger 1997, Jaramillo and Burke 1999). Northern populations are migratory, Great Lakes populations moving $1000 \mathrm{~km}$ on average (Dolbeer 1982). In this note, we document the first record of the Common Grackle for Sonora and summarize the status of the species in Mexico.

As part of the annual Álamos Christmas Bird Count, we, with Deirdre O'Connell and John Gorey, stopped at the Álamos landfill $\left(26^{\circ} 59^{\prime} 52^{\prime \prime} \mathrm{N}, 108^{\circ} 56^{\prime} 01^{\prime \prime}\right.$ W) on 17 December 2017, 15:10, where Harter spotted an immature Common Grackle. Recognizing the species' rarity, we immediately obtained photos. Over the next two days, the bird was seen by 15 observers and was last reported on 18 December. It was feeding in trash with a flock of Bronzed Cowbirds (Molothrus aeneus). The flock occasionally flew into the edges of nearby tropical deciduous forest. Field identification was based on the grackle's being slightly larger than the Bronzed Cowbirds, having a longer tail and heavier bill (Figure 1), and having an iridescent blue-green head, neck, and upper chest that contrasted strongly with the iridescent bronzed body. The tail and wings showed an iridescent purple tinge (Figure 2). The bronze body color identifies the subspecies as Q. q. versicolor, the Bronzed Grackle (Pyle 1997, Jaramillo and Burke 1999), which accounts for all records of vagrant Common Grackles west of the Rocky Mountains (Peer and Bollinger 1997). The bird was in its year of hatching (immature) by the dull brown eye, which only showed a hint of yellow in certain lights (see Pyle 1997).

This species is a late fall migrant; records of fall vagrants extend as late as mid December, merging into those of wintering (Hamilton et al. 2007b, Rosenberg et al. 2011). As this individual was likely not looked for after 18 December (David MacKay pers. comm.), we cannot know if it was a late fall migrant or attempted to overwinter. The Common Grackle shows a pattern of vagrancy in the southwestern United States just north of Sonora. There have been 33 records in Arizona through 2014 (Rosenberg et al. 2017), of which roughly half represent fall migrants scattered throughout the state, and roughly a sixth are from lowland southern Arizona in winter. California had 100 records as of 2015 (Searcy et al. 2018). In New Mexico, the species breeds in the northern and central parts of the state but winters largely farther east, though it is regular in winter in west Texas (Jaramillo and Burke 1999) and flocks have been found in winter in southern New Mexico, mainly along the Rio Grande (www.eBird.org, accessed 26 March 2018). We are unaware of any prior records for Sonora, where the Common Grackle was not reported by Russell and Monson (1998). Neither are there reports via www.eBird.org or www.iNaturalist.org or any known to H. Gómez de Silva (pers. comm.). We know of four prior records from western Mexico, three from El Rosario, Baja California, of one 9-21 January 1996 (Erickson et al. 2001), one 21 February 2003 (Hamilton et al. 2003), and two 26-27 December 2006, of which one continued until 26 February 2007 (Hamilton et al. 2007a). The fourth is from Rancho El Descanso $43 \mathrm{~km}$ east of El Rosario, 12 December 2000 (Hamilton et al. 2001). The species has been reported multiple times in northeastern Mexico (Howell and Webb 1995), but we are only aware of a single well-documented report prior to 2018, of one photographed (fide H. Gómez de Silva) in Gómez Farías, Tamaulipas, on 24 January 2014 (www.eBird.org). 


\section{NOTES}

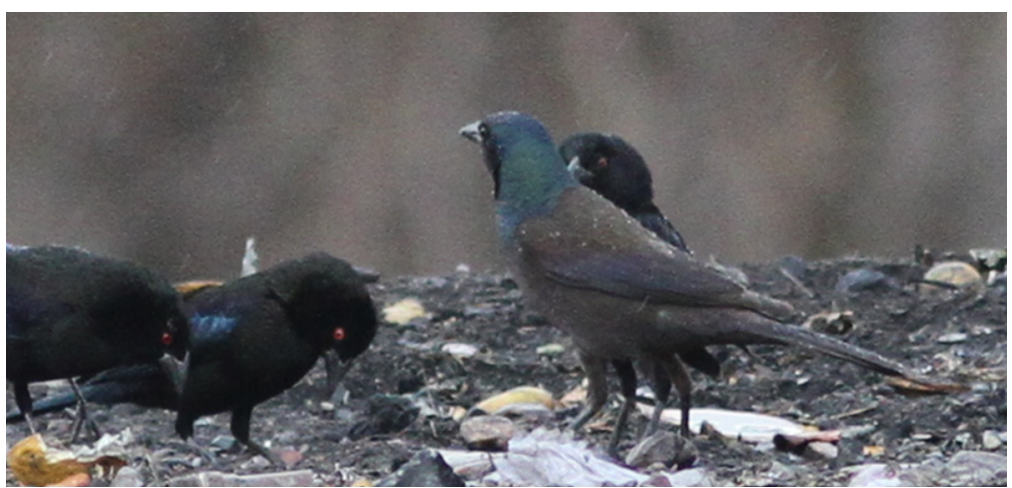

Figure 2. This Common Grackle at Álamos, Sonora, 17 December 2017, showed the characteristic plumage pattern of the Bronzed Grackle, subspecies versicolor, with brownish body plumage and a contrasting bluish hood (macaulaylibrary.org/ asset/79010691).

Photo by David Vander Pluym

Thanks to Richard A. Erickson, who provided us with information on the Baja California records, and to Héctor Gómez de Silva, who examined the Tamaulipas photograph. We thank David MacKay for hosting and compiling the Álamos Christmas Bird Count. We also thank Daniel D. Gibson, Robert A. Hamilton, and Andrew B. Johnson for helpful reviews that further improved the manuscript.

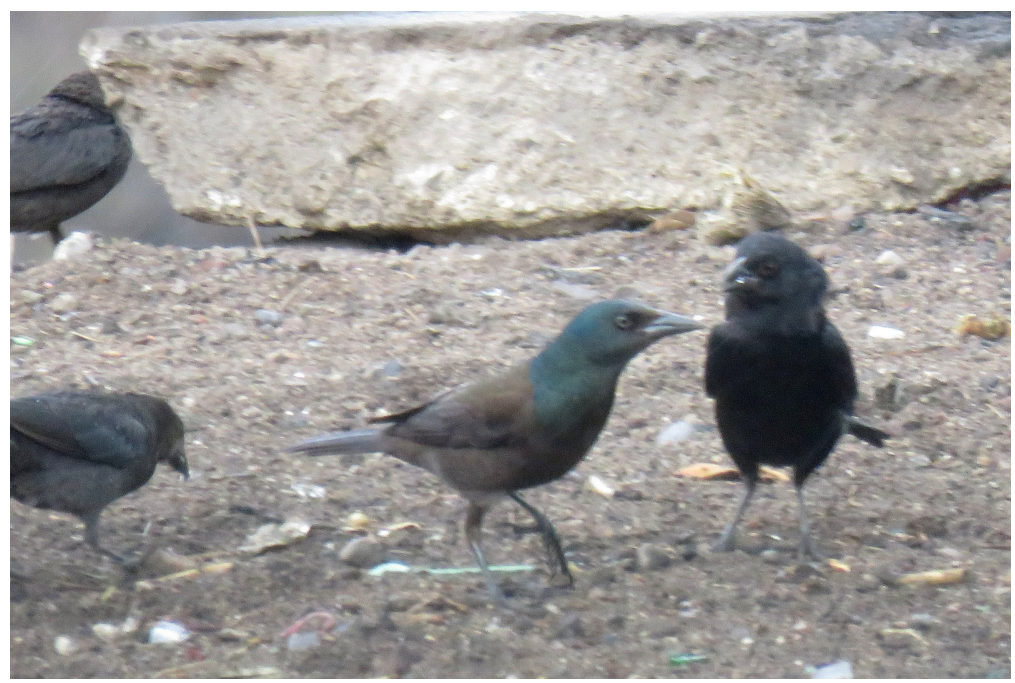

Figure 1. Common Grackle foraging among Bronzed Cowbirds at Álamos, Sonora, 17 December 2017. Note the long, stout bill (macaulaylibrary.org/asset/81984001). 


\section{NOTES}

\section{LITERATURE CITED}

Dolbeer, R. A. 1982. Migration patterns for age and sex classes of blackbirds and starlings. J. Field Ornithol. 53:28-46.

Erickson, R. A., Hamilton, R. A., and Howell, S. N. G. 2001. New information on migrant birds in northern and central portions of the Baja California Peninsula, including species new to Mexico, in Birds of the Baja California Peninsula: Status, Distribution, and Taxonomy (R. A. Erickson and S. N. G. Howell, eds.), Am. Birding Assoc. Monogr. Field Ornithol. 3:112-170.

Hamilton, R., A., Erickson, R. A., and Palacios, E. 2001. Baja California Peninsula region (winter 2000-2001). N. Am. Birds 55:231.

Hamilton, R., A., Erickson, R. A., Palacios, E., and Carmona, R. 2003. Baja California Peninsula region (winter 2002-2003). N. Am. Birds 57:262.

Hamilton, R. A., Billings, M. J., Carmona, R., and Ruiz-Campos, G. 2007a. Baja California Peninsula Region (winter 2006-2007). N. Am. Birds 61:333.

Hamilton, R. A., Patten, M. A., and Erickson, R. A. (eds). 2007b. Rare Birds of California. W. Field Ornithol,. Camarillo, CA.

Howell, S. N. G., and Webb, S. 1995. A Guide to the Birds of Mexico and Northern Central America. Oxford Univ. Press, Oxford, England.

Jaramillo, A., and Burke, P. 1999. New World Blackbirds: The Icterids. Princeton Univ. Press, Princeton, NJ.

Peer, B. D., and Bollinger, E. K. 1997. Common Grackle (Quiscalus quiscula), in The Birds of North America (A. F. Poole and F. B. Gill, eds.), no. 271. Acad. Nat. Sci., Philadelphia; doi 10.2173/bna.271.

Pyle, P. 1997. Identification Guide to North American Birds, part 1. Slate Creek Press, Bolinas, CA.

Rosenberg, G. H., Radamaker, K., and Stevenson, M. M. 2011. Arizona Bird Committee report, 2005-2009 records. W. Birds 42:198-232.

Rosenberg, G. H., Radamaker, K., and Vander Pluym, D. 2017. Arizona Bird Committee report, 2010-2014 records. W. Birds 48:74-112; doi 10.21199/ WB48.2.1.

Russell, S. M., and Monson, G. 1998. The Birds of Sonora. Univ. Ariz. Press, Tucson.

Searcy, A. J., Daniels, B. E., Feenstra, J. S., Tietz, J. R., and Benson, T. A. 2018. The $41^{\text {st }}$ annual report of the California Bird Records Committee: 2015 records. W. Birds 49:24-46; doi 10.21199/WB49.1.2. 